\title{
On serendipity and innovations in public health
}

\author{
Tam-Tri Le \\ Centre for Interdisciplinary Social Research \\ Phenikaa University, Hanoi, Vietnam \\ 2022 January 16 \\ OSF Preprints
}

Arguably the basic mission of humanity as a species is to survive and extend human existence to future generations; naturally, this leads to desires to become the "fittest" in one's environment and overcome existential threats, as suggested by the Darwinist theory of evolution (Darwin, 2003). The struggles for survival are not only limited to finding food, shelter, or avoiding predators that we often see in ancient human society. Existential threats are always present, and desires for surviving never cease.

Modern antibiotics are almost taken for granted in today's world, and many people may forget that they all started from the invention of penicillin just in the last century. In 1928, Alexander Fleming observed some Petri dishes containing Staphylococcus bacteria and noticed something strange in one dish. The Staphylococcus colonies did not appear in the area where a type of mold was growing (later identified as Penicillium notatum). This serendipity moment was what led to the large-scale production of penicillin as an antibiotic for human treatment during World War II. Without antibiotics, infections, even from small injuries, can become life-threatening problems. Notably, in the 1918 influenza pandemic that killed more than 50 million people, most deaths were attributed to secondary bacterial pneumonia (Sheng et al., 2011). While the issue of secondary bacterial pneumonia is also present in the ongoing Covid-19 pandemic, the widespread use of antibiotics today greatly reduces the severity of the disease and contributes to the lower mortality rate compared to the 1918 pandemic (Ginsburg \& Klugman, 2020).

On another important point about the Covid-19 pandemic, the miraculously rapid vaccine development was not due to pure luck nor being carelessly rushed, but it was systematically based on our collective knowledge, including the use of prior sequencing of the human genome and SARS-CoV-2 genome (Kames et al., 2020), as well as decades of vaccine research. The Covid19 vaccine development, production, and distribution process can be considered an information process that includes the application of serendipity together with the Mindsponge information filtering framework and the 3D principles of creativity (Napier \& Vuong, 2013; Q.-H. Vuong et al., 2022; Q. H. Vuong \& Napier, 2014). Some may perceive science as costly, but considering what it has been bringing to humanity, it is the right cost (Quan-Hoang Vuong, 2018).

The drive from survival desires helps set the conditions for serendipity through making preparations in terms of knowledge as well as the "big questions". To find the "missing pieces", survival purposes determine the "what" while the Mindsponge mechanism (Q. H. Vuong, 2016; 
Q. H. Vuong \& Napier, 2015) and the 3D principles determine the "how" (Q. H. Vuong \& Napier, 2014).

Update: More detailed discussions in the full book "A New Theory of Serendipity: Nature, Emergence and Mechanism" (see References).

\section{Acknowledgement}

I would like to thank my mentor Dr. Quan-Hoang Vuong and my friend Minh-Hoang Nguyen for the insights.

\section{References}

Darwin, C. (2003). On the origin of species (D. Knight Ed. Reprint ed.). London: Routledge.

Ginsburg, A. S., \& Klugman, K. P. (2020). COVID-19 pneumonia and the appropriate use of antibiotics. The Lancet Global Health, 8(12), e1453-e1454. doi:10.1016/S2214-109X(20)30444-7

Kames, J., Holcomb, D. D., Kimchi, O., DiCuccio, M., Hamasaki-Katagiri, N., Wang, T., ... Kimchi-Sarfaty, C. (2020). Sequence analysis of SARS-CoV-2 genome reveals features important for vaccine design. Scientific Reports, 10(1), 15643. doi:10.1038/s41598-020-72533-2

Napier, N., \& Vuong, Q. H. (2013). Serendipity as a Strategic Advantage? In T. Wilkinson (Ed.), Strategic Management in the 21st Century (pp. 175-199). Westport, CT: Praeger/ABC-Clio.

Sheng, Z. M., Chertow, D. S., Ambroggio, X., McCall, S., Przygodzki, R. M., Cunningham, R. E., .. . Taubenberger, J. K. (2011). Autopsy series of 68 cases dying before and during the 1918 influenza pandemic peak. Proceedings of the National Academy of Sciences, 108(39), 1641616421. doi:10.1073/pnas.1111179108

Vuong, Q.-H. (2018). The (ir)rational consideration of the cost of science in transition economies. Nature Human Behaviour, 2(1), 5. doi:10.1038/s41562-017-0281-4

Vuong, Q.-H., et al. (2022). Covid-19 vaccines production and societal immunization under the serendipity-mindsponge-3D knowledge management theory and conceptual framework. Humanities and Social Sciences Communications, 9, forthcoming.

Vuong, Q. H. (2016). Global Mindset as the Integration of Emerging Socio-Cultural Values Through Mindsponge Processes : A Transition Economy Perspective. In J. Kuada (Ed.), Global Mindsets: Exploration and Perspectives (pp. 109-126). London: Routledge.

Vuong, Q. H., \& Napier, N. K. (2014). Making creativity: the value of multiple filters in the innovation process. International Journal of Transitions and Innovation Systems, 3(4), 294-327. doi:10.1504/IJTIS.2014.068306

Vuong, Q. H., \& Napier, N. K. (2015). Acculturation and global mindsponge: An emerging market perspective. International Journal of Intercultural Relations, 49, 354-367. doi:10.1016/j.ijintrel.2015.06.003

Quan-Hoang Vuong. (2022). A New Theory of Serendipity: Nature, Emergence and Mechanism. Berlin, Germany: De Gruyter. 
